\title{
Hybrid fuzzy dan Naive Bayes Dalam Penentuan Status UKT (Studi Kasus Program Studi Teknik Informatika Universitas Khairun )
}

\author{
Anas $^{1}$, Firman Tempola ${ }^{2}$, Amal Khairan ${ }^{3}$ \\ ${ }^{1,2,3}$ Program Studi Teknik Informatika, Fakultas Teknik, Universitas Khairun \\ Jl.Jati Metro, Kota Ternate Selatan \\ E-mail :anasna0101@ gmail.com ${ }^{1}$, firman.tempola@unkhair.ac.id ${ }^{2}$, ibntawakkal@ gmail.com ${ }^{3}$
}

\begin{abstract}
Abstrak -- Uang Kuliah Tunggal (UKT) merupakan nama dari sebuah sistem pembayaran yang saat ini berlaku diseluruh PTN. Ketentuan ini berdasarkan Permendibud No. 55 Tahun 2013 asal 1 ayat 3 yakni setiap mahasiswa hanya membayar satu komponen. Jumlah mahasiswa baru di Universitas Khairun yang begitu banyak dan kuota per UKT terbatas maka terkadang dalam hal penentuan status UKT masih terdapat ketidaksesuain dengan ekonomi Mahasiswa. Oleh karena itu dibutuhkan aplikasi penentuan status UKT yang lebih akurat. Tujuan dari penelitian ini yaitu untuk membuat aplikasi penentuan status UKT dengan menggunakan metode Fuzzy dan Naive Bayes dan membandingkan akurasi Naive Bayes dan akurasi dari kombinasi metode Fuzzy dan Naive Bayes. Untuk membandingkan akurasi Naive Bayes dan Fuzzy Naive Bayes peneliti melakukan 2 percobaan dengan menggunakan data training sebanyak 50 dan data testing sebanyak 20 , percobaan pertama diakukan dengan mengguakan4 kriteria, dengan metode Naive Bayes hasil akurasi yaitu 70\%, dan metode Fuzzy Naive Bayes hasil akurasi yaitu $55 \%$, percobaan kedua dilakukan dengan menggunakan 6 kritaria, dengan metode Naive Bayes hasil akurasi yaitu $90 \%$ dan dengan menggunakan Fuzzy Naive Bayes hasil akurasi mencapai $85 \%$. Dari penelitian tersebut diketahui bahwa akurasi Naive Bayes lebih tinggi dari pada akurasi Fuzzy Naive Bayes dan jumlah kriteria sangat berpengaruh dalam peningkatan akurasi.
\end{abstract}

Kata Kunci : UKT, Fuzzy, Naive Bayes

\section{Pendahuluan}

UKT adalah singkatan dari Uang Kuliah Tunggal yang merupakan nama dari sebuah sistem pembayaran yang saat ini berlaku diseluruh PTN. Ketentuan ini berdasarkan Permendibud No 55 Tahun 2013 pasal 1 ayat 3 yakni setiap mahasiswa hanya membayar satu komponen [1].

UKT memberikan subsidi silang yang didasarkan pada kondisi ekonomi dan sosial orang tua/wali mahasiswa. Yang menjadi ciri khas UKT yakni pengelompokan biaya UKT berdasarkan kemampuan orang tua. pengelompokan biaya UKT diharapkan dapat memberikan kemudahan bagi keluarga yang kurang mampu dalam segi ekonomi, sehingga setiap mahasiswa pembayaran UKT-nya tidak sama, semua tergantung pada kemampuan perekonomian keluarga, Namun karena jumlah mahasiswa baru di Universitas Khairun yang begitu banyak dan kuota per UKT terbatas maka terkadang dalam hal penentuan status UKT masih terdapat ketidaksesuain dengan ekonomi
Mahasiswa. Oleh karena itu di perlukan sebuah aplikasi yang dapat menentukan status UKT yang lebih akurat.

Sebelumnya, pada kasus UKT sudah pernah di teliti oleh Agus Setiyo Budi N dan M. Rizqon Ramadhan dengan judul "Sistem Pakar Menentukan Kategori UKT Mahasiswa Menggunakan Metode Fuzzy Tsukamoto Pada Politeknik Negeri Banjarmasin" dan oleh Ani Sholihah dengan judul "Sistem Pendukung Keputusan Penentuan Uang Kuliah

Uang Kuliah Tunggal (UKT) Dengan Metode Naive Bayes Di Universitas Trunojoyo Madura. Pada Penelitian tersebut menggunakan kriteria penghasilan orang tua, jumlah tanggungan, ukuran rumah besaran rekening listrik dan besaran rekening PDAM. Hasil akurasi pada penelitian tersebu yaitu $82 \%$.

Pada penelitian ini, akan dilakukan kombinakasi metode Fuzzy dan metode Naive Bayes dalam kasus yang sama akan tetapi kriteria yang berbeda. Penelitian penggabungan metode Fuzzy dan Naive Bayes sudah pernah dilakukan sebelumnya dengan judul "Fuzzy Naive Bayesian For Constructing Reulated Network With Weight" dan mendapatkan akurasi yang cukup baik, dari itu peneliti berharap bisa mendapatkan Tingkat Akurasi yang cukup tinggi setelah menggunakan metode Fuzzy Naive Bayes dalam kasus penentuan UKT.

Fuzzy adalah pemakaian fungsi keanggotaan untuk menentukan seberapa besar suatu predikat memenuhi suatu fungsi, penalaran logika Fuzzy sangat sederhana dan mudah di menegerti serta daya guna Metode Fuzzy dianggap lebih baik daripada teknik kendali yang pernah ada [2].

Algoritma Naive Bayes merupakan sebuah metoda klasifikasi menggunakan metode probabilitas dan statistik. Keuntungan penggunan Naive Bayes adalah bahwa metode ini hanya membutuhkan jumlah data pelatihan (training data) yang kecil untuk menentukan estimasi parameter yg diperlukan dalam proses pengklasifikasian. Pemanfaatan naive bayes pernah dilakukan oleh [6] pada penentuan status gunung berapi.

\section{TINJAUAN PUSTAKA}

\subsection{Fuzzy}

Dalam bahasa inggris, Fuzzy mempunyai arti kabur atau tidak jelas. Jadi, logika Fuzzy adalah logika yang kabur, atau mengandung unsur ketidakpastian. Logika Fuzzy mengenal nilai antara benar dan salah, kebenaran dalam logika Fuzzy dinyatakan dalam fungsi keanggotaan yang nilainya 0 sampai $1[3]$. 
Fungsi keanggotaan adalah suatu kurva yang menunjukkan pemetaan titik-titik Input data kedalam nilai keanggotaannya (sering juga disebut dengan derajat keanggotaan) yang memiliki interval 0 sampai 1 . salah satu cara yang dapat digunakan untuk mendapatkan nilai keanggotaan adalah dengan melalui pendekatan fungsi.

\subsection{Representasi Linear}

Pada representasi linear, pemetaan Input ke derajat keanggotaannya di gambarkan sebagai suatu garis lurus. Bentuk ini paling sederhana dan menjadi pilihan yang baik untuk mendekati suatu konsep yang kurang jelas [4].

Ada 2 keadaan himpunan Fuzzy yang linear:

1. garis lurus dimulai dari nilai domain dengan derajat keanggotan tertinggi pada sisi kiri, kemudian bergerak menurun ke nilai domain yang memiliki derajat keanggotaan yang lebih rendah. Representasi linear turun dapat dilihat pada gambar 1 .

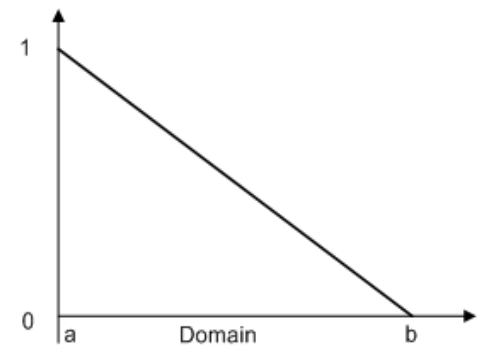

Gambar 1. Representasi linear turun

Rumus fungsi keanggoaan representasi linear turun

$$
\left\{\begin{array}{c}
1 ; x \leq a \\
\frac{b-x}{b-a} ; a \leq x \leq b \\
0 ; x \geq b
\end{array}\right\}
$$

2. Kenaikann Himpunan di mulai pada nilai domain yang memiliki derajat keanggotaan nol (0) bergerak ke kanan menuju ke nilai domain yang memiliki derajat keanggotaan lebih tinggi, Representasi linear naik dapat dilihat pada gambar 2 .

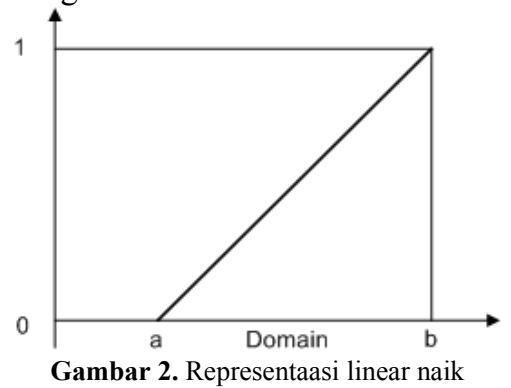

Rumus fungsi keanggotaan representasi linear naik

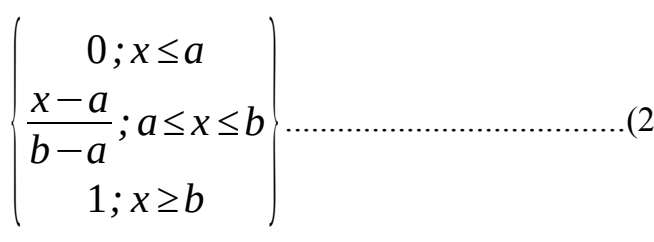

\subsection{Naive Bayes}

Algoritma Naive Bayes merupakan sebuah metode klasifikasi menggunakan metode probabilitas dan statistik yg dikemukakan oleh ilmuwan Inggris Thomas Bayes. Algoritma Naive Bayes memprediksi peluang di masa depan berdasarkan pengalaman di masa sebelumnya sehingga dikenal sebagai Teorema Bayes [5].

Keuntungan penggunan adalah bahwa metoda ini hanya membutuhkan jumlah data pelatihan (training data) yang kecil untuk menentukan estimasi parameter yang diperlukan dalam proses pengklasifikasian. Karena yang diasumsikan sebagai variabel independent, maka hanya varians dari suatu variabel dalam sebuah kelas yang dibutuhkan untuk menentukan klasifikasi, bukan keseluruhan dari matriks kovarians.

\section{Tahapan Naive Bayes}

1. Menghitung Mean dan Standar Deviasi (Data Numerik)

Mencari Mean dapat dilihat pada persamaan 3.

$$
\dot{x}=\frac{1}{n} \sum_{i=1} x_{i}
$$

2. Mencari Standar Deviasi dapat dilihat pada persamaan 4.

$$
s^{2}=\frac{\sum_{i=1}\left(x_{i}-\dot{x}\right)^{2}}{n-1}
$$

3. Menghitung Probabilitas (Data Diskrit) dapat dilihat pada persamaan 5 .

$\mathrm{P}(\mathrm{E})=\mathrm{X} / \mathrm{N}$

4. Menghitung Densitas gauss dapat dilihat pada persamaan 6 .

$$
f\left(x_{i}\right)=\frac{1}{\sqrt{2 \pi} \sigma} e^{\frac{-(x-\mu)^{2}}{2 \sigma^{2}}}
$$

5. Menghitung Likelihood dapat dilihat pada persamaan 7.

$$
L(x)=f\left(x_{1}\right) \times f\left(x_{2}\right) \times \ldots \times f\left(x_{n}\right)
$$

6. Menghitung Probabilitas Likelihood dapat dilihat pada persamaan 8 .

$$
P\left(L_{i}\right)=\frac{L_{i}}{\sum_{i=1} L_{i}}
$$

\section{METODE PENELITIAN}

\subsection{Objek Penelitian}

Penulis melakukan penelitian terhadap pembuatan aplikasi status UKT menggunakan Fuzzy Naive Bayes dan perbandingan akurasu Naive Bayes dan Fuzzy Naive Bayes.

\subsection{Metode Pengumpulan Data}

Pengumpulan data melalui data Dokumen, yaitu Pengambilan data melalui dokumen tertulis dari Tim UKT Universitas Khairun.

\subsection{Metode Pengembangan Sistem}

Metode pengembangan yang digunakan dalam pembuatan aplikasi penentuan status UKT adalah metode Prototype. Metode prototype adalah metode dalam 
pengembangan rekayasa software yang bertahap dan berulang, serta mementingkan sisi user sistem. Metode Pengembangan Aplikasi yang digunakan untuk membangun aplikasi kriptografi SMS yaitu dengan menggunakan metode prototype yang terdiri dari 5 tahapan pengembangan perangkat lunak yaitu Tahap Komunikasi, Tahap Perencanaan secara cepat, Tahap Pemodelan Perancangan secara cepat, Tahap Pembentukan Prototype, Tahap Pembuatan Sistem Serta Penyerahan \& Umpan Balik. Berikut tahapan-tahapan pada model prototype ini dapat dilihat pada gambar dibawah ini:

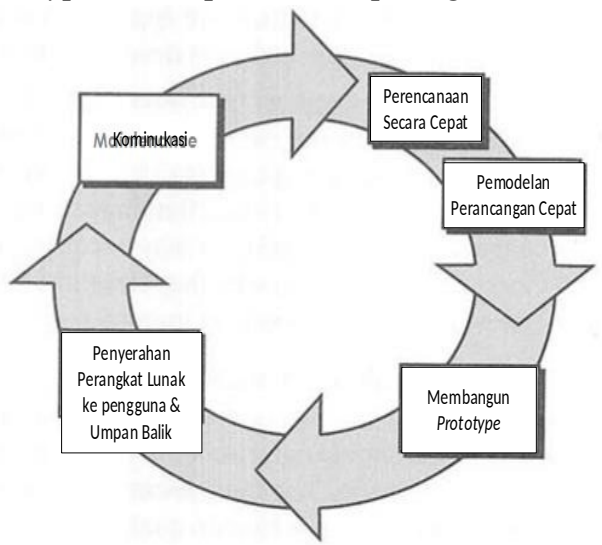

Gambar 3. Metode Prototype

1. Tahap Komunikasi: Pada tahap ini, Peneliti akan mengumpulkan data UKT, kemudian mengidentifikasikan secara garis besar kebutuhan apa saja yang akan digunakan dalam pembuatan aplikasi penentuan status UKT menggunakan metode Fuzzy Naive Bayes

2. Tahap Perencanaan secara cepat: Pada tahap Perencanaan pembuatan prototyping dilakukan secara cepat, namun dalam bentuk rencana awal. Hasil dari rencana awal peneliti yakni, Flowchart meode Naive Bayes, Flowchart metode Fuzzy Naive Bayes, Use Case Diagram dan perancangan database.

3. Tahap Pemodelan Perancangan Secara Cepat: Pada tahap ini peneliti akan menganalisa kebutuhan-kebutuhan perangkat lunak yang akan di butuhkan nantinya dan peneliti akan membuat desain interface aplikasi penentuan status UKT.

4. Tahap Pembentukan Prototype: Pada tahap ini peneliti akan melakukan penulisan kode kedalam bahasa pemrograman PHP sesuai dengan tahap perancangan yang telah dibuat dan tools yang telah ditentukan sebelumnya. Kemudian akan dilakukan pengujian sistem dengan White box testing. Tahap pengujian ini bertujuan untuk menunjukan apakah algoritma dalam program telah sesuai.

5. Tahap Pembuatan Sistem serta Penyerahan \& Umpan Balik: Sistem yang sudah lulus tahapan pengujian dibuat prototype untuk kemudian diserahkan ke pengguna atau pengembang sistem.

\subsection{Perancangan Aplikasi}

Pada tahap ini penulis akan menggambarkan sistem yang akan dibangun dengan menggunakan Use Case Diagram sebagai media visualisasi sebuah perangkat lunak atau sistem. Adapun Use Case Diagramnya dapat dilihat pada gambar 4.

Berdasarkan Gambar 4, User dapat mengakses dan melakukan beberapa hal yaitu:
1. User dapat mengakses dataset, di dalam dataset ada 2 menu yaitu menu dataset dan menu data Fuzzy, menu dataset adalah menu untuk melihat data UKT asli, sedangkan menu data Fuzzy adalah menu untuk melihat data UKT yang sudah dihitung menggunakan metode Fuzzy.

2. User dapat Melihat Hasil Hitung berdasarkan metode Naive Bayes dan Fuzzy.

3. User dapat mengInput data baru yang akan diklasifikasi menggunakan metode Naive Bayes dan metode Fuzzy Naive Bayes.

4. User dapat melihat data-data yang telah diklasifikasi menggunkan metode Naive Bayes dan Fuzzy Naive Bayes.

User dapat menentukan jumlah data training untuk menghitung akurasi.

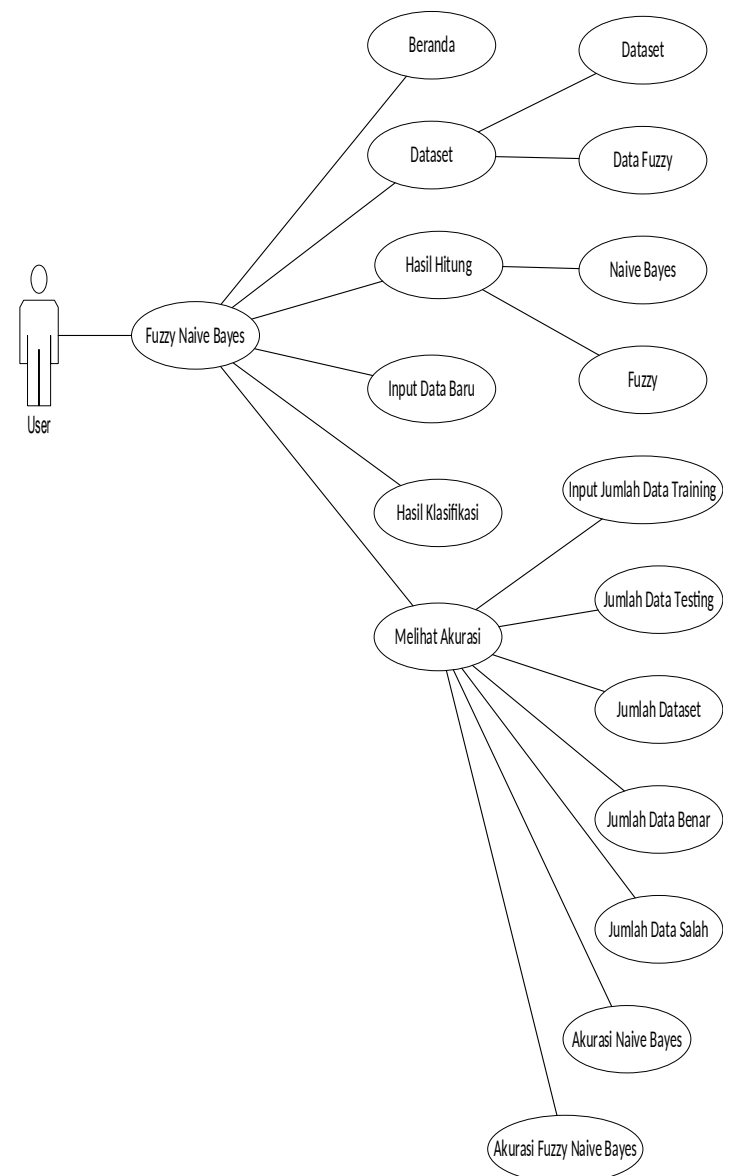

Gambar 4. Use Case Diagram

\section{HASIL DAN PEMBAHASAN}

\subsection{Analisis Data}

Pada tahap ini dibahas tentang bagaimana mengklasifikasi status UKT mahasiswa dan mencari akurasi metode yang digunakan dengan kriteria-kriteria yang telah ditentukan oleh peneliti dengan jumlah data yang digunakan sebanyak 99 data yang diambil dari tim UKT Universitas Khairun. 


\subsection{Flowchart}

Flowchart atau Diagram Alir ini memperlihatkan tahaptahap proses metode yang digunakan yaitu metode Naive Bayes dan Fuzzy Naive Bayes.

1. Flowchart Naive Bayes

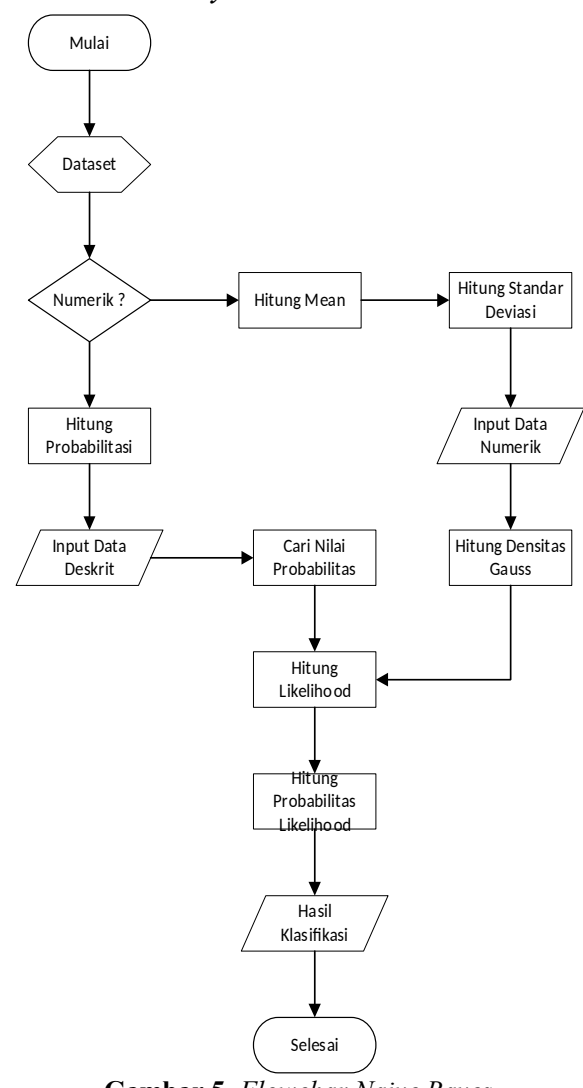

Gambar 5. Flowchar Naive Bayes

\section{Flowchart Fuzzy Naive Bayes}

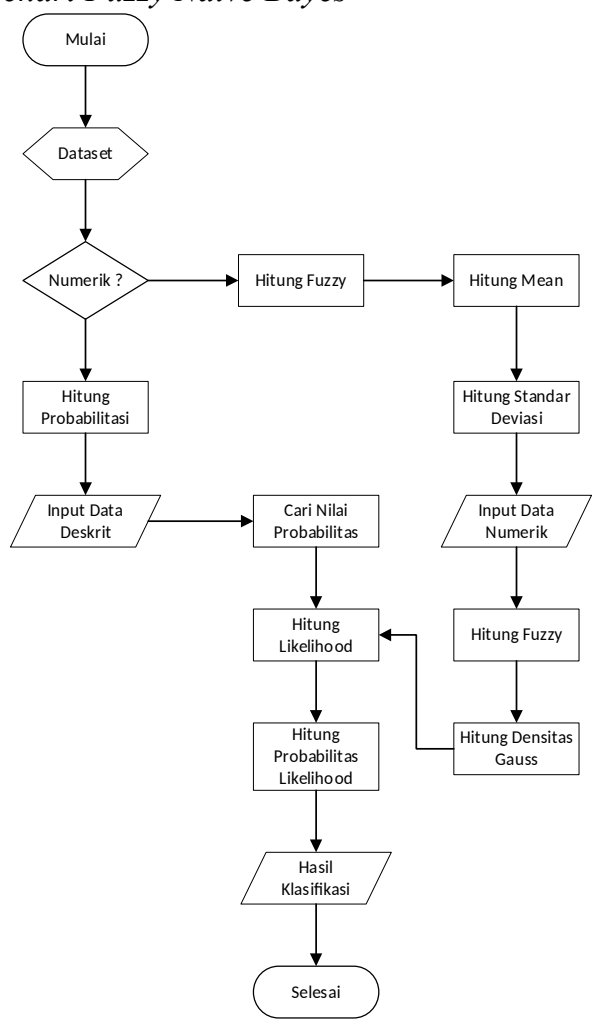

Gambar 6. Flowchart Fuzzy Naive Bayes

\subsection{Imlementasi Interfaces}

Dalam aplikasi penentuan stastus UKT menggunakan Fuzzy Naive Bayes ini mengimplemtasikan beberapa interfaces utama. Diantaranya adalah:

1. Tampilan Menu Input: Halaman menu Input menampilkan form Inputan untuk klasfikasi data baru. Tampilan menu Input dapat dilihat pada gambar 7.

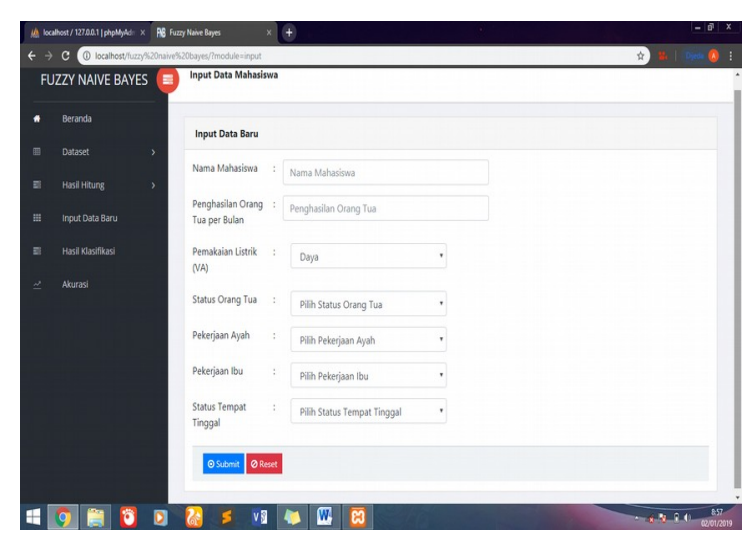

Gambar 7.Tampilan Menu Input

2. Tampilan Hasil Klasifikasi: Tampilan halaman Hasil Klasifikasi menampilkan hasil klasifiasi dari metode Naive Bayes dan Fuzzy Naive Bayes yang telah di Input dimenu Input. Tampilan halaman Hasil Kasifikasi dapat dilihat pada gambar 8 .

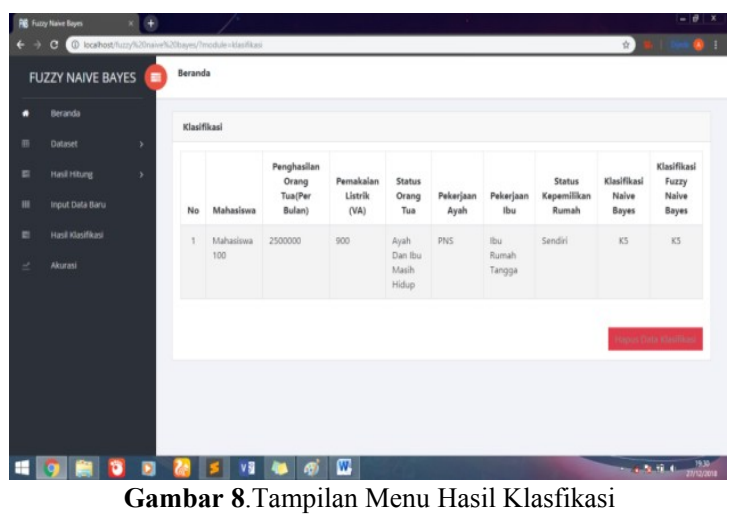

3. Tampilan Akurasi: Tampilan halaman Akurasi menampilkan form Inputan jumlah data testing dan data trainig yang akan digunakan untuk menghitung akurasi setelah proses maka akan ditampilkan hasil akurasi dari metode Naive Bayes dan Fuzzy Naive Bayes. Tampilan Halaman pesan masuk dapat dilihat pada gambar 9 .

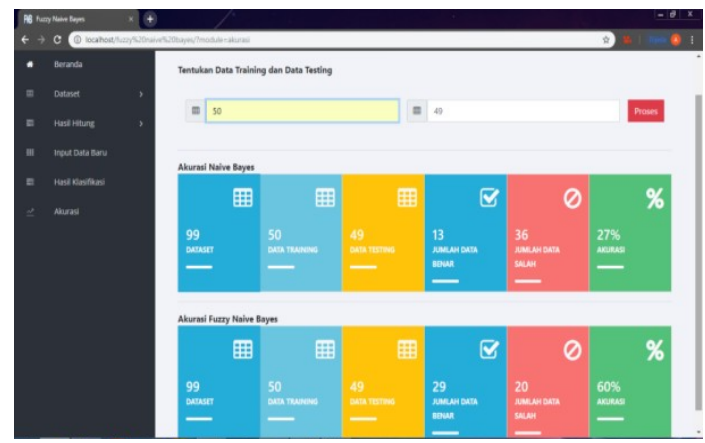

Gambar 9. Tampilan Akurasi 


\subsection{Akurasi}

Untuk membandingkan akurasi metode Naive Bayes dan Fuzzy Naive Bayes, dilakukan pengujian metode yaitu:

1. Pengujian Naive Bayes

Pada pengujian ini digunakan 50 Data training dan 20 data testing. Pengujian pertama menggunakan 4 kriteria yaitu penghasilan orang tua, daya pemakaian listrik, status orang tua, dan kepemilikan rumah, setelah dihitung didapatkan 14 data benar dan 6 data salah sehingga untuk mendapatkan akurasi dapat dihitung sebagai berikut:

$$
\frac{14}{14+6} X 100 \%=70 \%
$$

Jadi, dengan menggunakan 4 kriteria, tingkat akurasi Naive Bayes yang didapat adalah $70 \%$.

Pengujian kedua menggunakan 6 kriteria yaitu penghasilan orang tua, daya pemakaian listrik, status orang tua, kepemilikan rumah, pekerjaan ayah dan pekerjaan ibu, setelah dihitung didapat 18 data benar dan 1 data salah sehingga untuk mendapatkan akurasi dapat dihitung dengan cara berikut:

$$
\frac{18}{18+2} X 100 \%=90 \%
$$

Jadi, dengan menggunakan 6 krieria, tingkat Akurasi Naive Bayes sebesar 90\%.

2. Pengujian Fuzzy Naive Bayes

Pada pengujian ini digunakan data yang sama yaitu 50 Data training dan 20 data testing. Pengujian pertama menggunakan 4 kriteria yaitu penghasilan orang tua, daya pemakaian listrik, status orang tua, dan kepemilikan rumah, setelah dihitung didapat 11 data benar dan 9 data salah sehingga:

$$
\frac{11}{11+9} X 100 \%=55 \%
$$

Jadi, dengan menggunakan 4 kriteria, akurasi Fuzzy Naive Bayes yaitu 55\%.

Pengujian kedua menggunakan 6 kriteria yaitu penghasilan orang tua, daya pemakaian listrik, status orang tua, kepemilikan rumah, pekerjaan ayah dan pekerjaan ibu, setelah dihitung didapat 17 data benar dan 3 data salah sehingga akurasi dapat dihitung dengan cara sebagai berikut:

$$
\frac{17}{17+3} X 100 \%=85 \%
$$

Jadi, dengan menggunakan 6 kriteria, tingkat Akurasi Fuzzy Naive Bayes sebesar 85\%

\subsection{Pengujian Sistem}

Pengujian merupakan tahap yang utama dalam pembuatan suatu aplikasi perangkat lunak. Hasil pengujian yang didapat, akan dijadikan sebagai tolak ukur dalam proses pengembangan selanjutnya.

Pada pengujian ini dilakukan dengan menggunakan teknik White box, dimana terlebih dahulu memetakan Flowchart ke dalam flowgraph kemudian menghitung besarnya jumlah egde dan node dimana jumlah node dan edge ini akan menentukan besarnya cyclomatic complexcity. Adapun Flowchart dan flowgraph sistem yang dibangun. Metode yang digunakan pada pengujian ini yaitu Metode Naive Bayes.

Flowchart Naive Bayes dapat dilihat pada gambar 4.10.

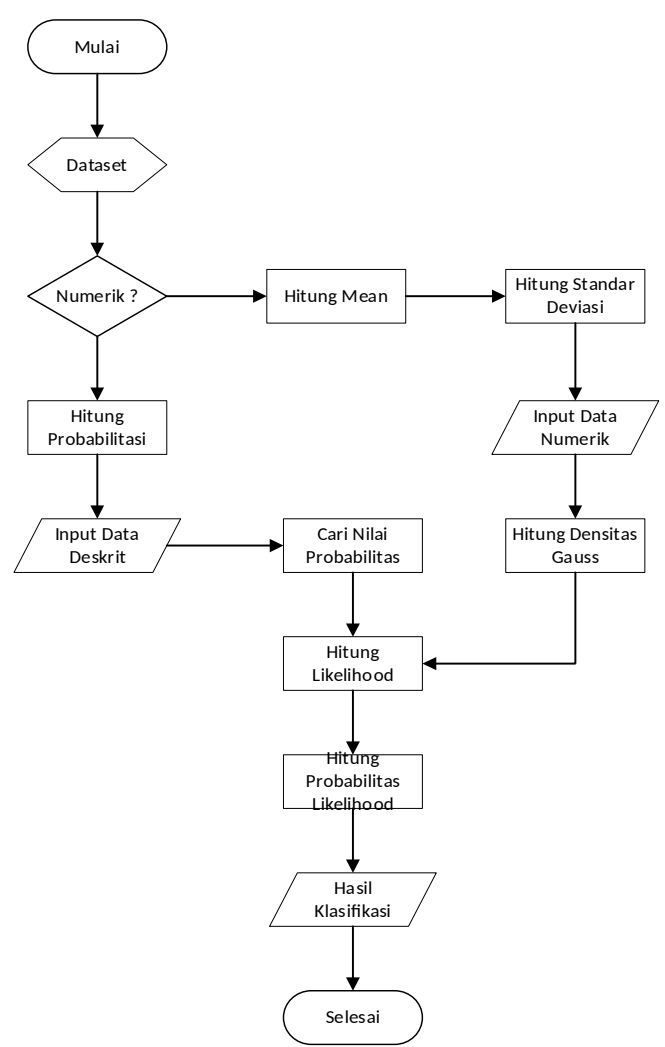

Gambar 4.10 Flowchart Naive Bayes Pesan

Pada Flowgrapgh Naive Bayes ini diambil dari Flowchart pada tampilan kirim pesan. Adapun Flowgraph dari Naive Bayes dapat dilihat pada gambar 4.11. 


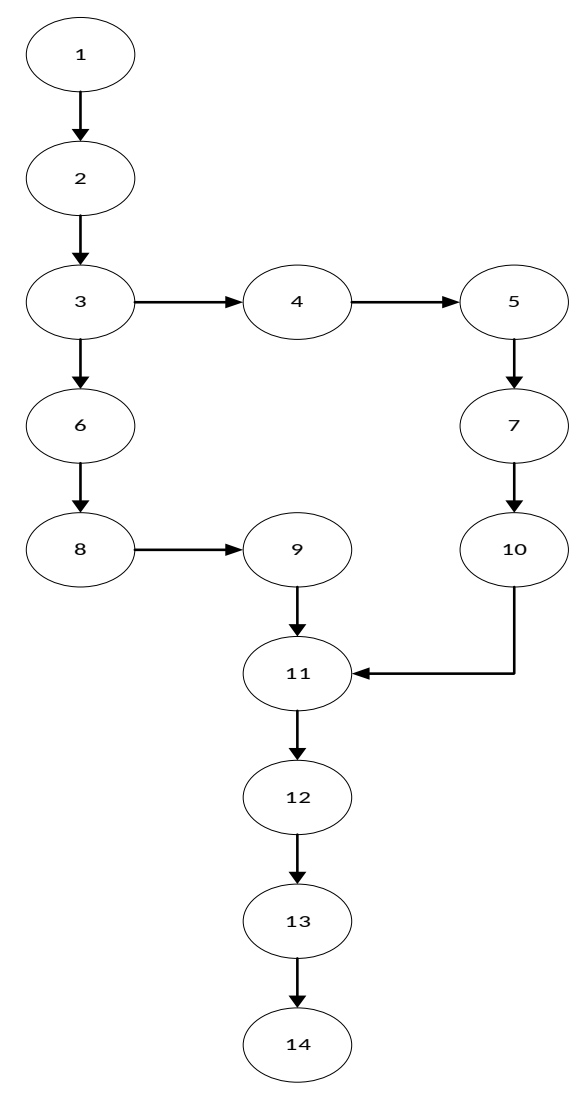

Gambar 4.11 Flowgraph Naive Bayes

Keterangan :

Node $(\mathrm{N}): 14$

Edge : 14

Predikat (P) : 1

Cyclomatic Complexity

$\mathrm{V}(\mathrm{G})=(\mathrm{E}-\mathrm{N})+2$ $=(14-14)+2$

$$
=2
$$

$\mathrm{V}(\mathrm{G})=\mathrm{P}+1$

$=1+1$

$=2$

Independen path :

Path $1=1-2-3-4-5-7-10-11-12-13-14$

Path $2=1-2-3-6-8-9-11-12-13-14$

Berdasarkan pada hasil yang didapatkan Cyclomatic Complexity, dan Independen Path bernilai 2 , maka dapat diambil kesimpulan bahwa pengujian White box berhasil.

\section{PENUTUP}

\subsection{Kesimpulan}

1. Pembuatan aplikasi penentuan status UKT dengan menggunakan metode Fuzzy dan Naive Bayes dimulai dengan menganalisis kebutuhan sistem yaitu dilakukan dengan meminta data UKT di tim UKT Unkhair dan studi pustaka, kemudian mendesain sistem yaitu yang dilakukan dengan pemodelan diagram alir (Flowchart) kedua metode dan perancangan database dengan menggunakan entity relationship diagram (ERD) serta perancangan interfaces atau antar muka. Setelah tahapan perancangan dilakukan, dimulai dengan tahapan implementasi sistem yaitu coding dan testing.
2. Membandingkan akurasi dengan cara melakukan beberapa percobaan yaitu mencari akurasi Naive Bayes dan Fuzzy Naive Bayes dengan menggunakan 4 kriteria dan percobaan berikutnya mencari akurasi Naive Bayes dan Fuzzy Naive Bayes dengan menggunakan 6 kriteria.

3. Saat mencari Akurasi data training yang digunakan sebanyak 50 dan data testing sebanyak 20. Dengan menggunakan 4 kriteria, akurasi Naive Bayes sebesar 70\% dan akurasi Fuzzy Naive Bayes sebesar 55\%, sedangkan dengan menggunakan 6 kriteria, akurasi Naive Bayes sebesar 90\% dan akurasi Fuzzy Naive Bayes sebesar 85\%,

4. Dalam penelitian ini nilai representasi linear terkecil tidak dapat digunakan dalam penormalisasian data karena nilai 0 yang didapat dari perhitungan Fuzzy mempengaruhi nilai Densitas Gauss sehingga bisa menurungkan tingkat akurasi Naive Bayes

5. Banyaknya kriteria mempengaruhi tingkat akurasi

\subsection{Saran}

1. Penelitian ini dapat dikembangkan dengan mengkombinasikan metode Naive Bayes dengan metode Fuzzy lainnya.

2. Penormalisasian data menggunakan Fuzzy menggunakan pendekatan fungsi representasi lainnya.

3. Sebaiknya jumlah data dan jumlah kriteria ditambah, sehingga dapat diperolah hasil akurasi yang lebih baik lagi.

\section{DAFTAR PUSTAKA}

[1] Permenristekdikti, "Biaya Kuliah Tunggal Dan Uang Kuliah Tunggal Pada Perguruan Tinggi Negeri Di Lingkungan Kementerian Riset, Teknologi, Dan Pendidikan Tinggi," 2015. [Online]. Available: http://kelembagaan.ristekdikti.go.id/wp-content/uploads/2016/08/Per menristekdikti22-2015BKT-UKT-PTN.

[2] A. Saelan, "LOGIKA FUZZY," no. 13508029, pp. 1-5, 2009.

[3] L. Zadeh, "Fuzzy sets." 1964.

[4] S. Kusumadewi, "Klasifikasi Status Gizi Menggunakan Naive Bayesian Classification," J. Univ. Binus, vol. 3, no. 1, pp. 6-11, 2009.

[5] A. A. Muin, "Metode Naive Bayes Untuk Prediksi Kelulusan ( Studi Kasus : Data Mahasiswa Baru Perguruan Tinggi )," vol. 2, no. 1, 2016.

[6] Tempola, F., Muhammad, M., dan Khairan, A.,"Perbandingan Klasifikasi antara KNN dan Naive Bayes pada Penentuan Status Gunung Berapi dengna K-Fold Cross Validation,"Jurnal Teknologi Informasi dan Ilmu Komputer (JTIIK), 2018. vol. 5, no. 5, 577-584. 